\title{
Peningkatan Kemampuan Penalaran Aljabar Siswa Melalui Problem Based Learning Dan Konvensional Pada Siswa Madrasah Tsanawiah
}

\author{
(Improvement Of Algebraic Reasoning Ability Students Through Problem Based Learning \\ And Conventional Madrasah Students On Tsanawiah) \\ Elfiyanti Sermatan ${ }^{1}$, Fahinu' ${ }^{2}$ Zamsir $^{2}$ \\ ${ }^{1}$ Alumnus Prodi Pendidikan Matematika PPs Universitas Halu Oleo \\ ${ }^{2}$ Dosen Pendidikan Matematika FKIP dan PPS Universitas Halu Oleo; Co-author: fahinu@uho.ac.id
}

\begin{abstract}
Abstrak: Penelitian ini bertujuan untuk: (1) Mengetahui perbedaan masalah penerapan problem based learning (PBL) dan pembelajaran konvensional terhadap kemampuan penalaran aljabar siswa sebelum diberikan perlakuan; (2) Mengetahui perbedaan peningkatan penerapan problem based learning dan pembelajaran konvensional terhadap kemampuan penalaran aljabar siswa setelah di berikan perlakuan. Populasi dalam penelitian ini adalah seluruh siswa kelas 8 MTS Negeri 1 Bau-Bau yang terdiri dari 6 kelas paralel. Teknik pengambilan sampel dalam penelitian menggunakan teknik purposive random class. Penentuan kelas eksperimen dilakukan secara random dan diperoleh siswa kelas 81 dengan jumlah siswa 34 orang sebagai kelas eksperimen Problem Based Learning dan siswa kelas 83 dengan jumlah siswa 30 orang sebagai kelas Konvensional. Teknik pengumpulan data dilakukan dengan pemberian tes kemampuan penalaran aljabar siswa berbentuk tes uraian, lembar observasi. Teknik analisis data menggunakan statistik deskriptif dan statistik inferensial dengan uji hipotesis menggunakan Uji Beda Dua Nilai Tengah dari data N-gain kemampuan penalaran aljabar siswa. Hasil penelitian menunjukkan bahwa: (1) Kemampuan penalaran aljabar siswa setelah pembelajaran problem based learning diperoleh 88,24\% dan Kemampuan penalaran aljabar siswa setelah pembelajaran Konvensional 11,767\% (2) Penerapan model problem based learning lebih baik daripada model pembelajaran konvensional terhadap kemampuan penalaran aljabar siswa;
\end{abstract}

Kata kunci: Penalaran Aljabar, Konvensional, Problem Based Learning

\begin{abstract}
This study aims to: (1) Know the difference of problem of application of problem based learning model (PBL) and conventional learning model to students algebra reasoning ability before given treatment; (2) to know the difference of application of problem based learning model and conventional learning model to students' algebraic reasoning ability after giving treatment. Population in this research is all student of 8th grade MTS Negeri 1 Bau-Bau which consist of 6 parallel class. The sampling technique used in this research is purposive random class technique. The determination of experimental class is done randomly and obtained by grade 81 students with 34 students as experimental class of Problem Based Learning and 83 graders with 30 students as Conventional class. Data collection technique is done by giving students algebra reasoning abilities test in the form of description test, observation sheet. Data analysis techniques used descriptive statistics and inferential statistics by hypothesis testing using Differential Test of Two Middle Values from N-gain data of students' algebraic reasoning abilities. The results showed that: (1) students 'algebraic reasoning ability after learning problem based learning was obtained $88.24 \%$ and students' algebraic reasoning ability after conventional learning $11,767 \%$ (2) Application of problem based learning model better than conventional learning model on algebraic reasoning ability Students.
\end{abstract}

Keywords: Algebraic reasoning, Conventional, Problem Based Learning

\section{PENDAHULUAN}

Aljabar merupakan cabang matematika yang sangat penting dalam membentuk karakter matematika anak, karena dengan alajabar anak dilatih berpikir kritis, kreatif, bernalar dan berpikir abstarak. Dengan alajabar pula, anak dikenalkan dengan variabel dan berbagai simbol matematika yang dapat digunakan untuk menyederhanakan kalimat menjadi model matematika dalam menyelesaikan masalah yang berkaitan dengan kehidupan sehari-hari. Kriegler 
(2011) mengatakan bahwa Aljabar merupakan pintu gerbang untuk memahami matematika lebih lanjut. Hal ini dapat disebabkan Aljabar memuat materi dasar matematika, seperti: himpunan, fungsi, dan kombinatorik. Materi himpunan dan fungsi menjadi dasar bagi bidang analisis. Materi kombinatorik menjadi dasar bagi bidang peluang dan statistika.

Pembelajaran matematika tidak hanya diajarkan untuk sekedar menghafal rumus-rumus matematika saja akan tetapi siswa juga harus dapat menggunakan ilmu matematika untuk memecahkan permasalahan yang ada disekitar kehidupan mereka. Permasalahan matematika yang berhubungan dengan kehidupan sehari-hari dalam mata pelajaran matematika akan membuat siswa mengerti dan memahami manfaat dari ilmu yang siswa pelajari. Matematika berfungsi mengembangkan kemampuan menghitung, mengukur, menurunkan dan menggunakan rumus matematika. Matematika juga berfungsi mengembangkan kemampuan mengkomunikasikan gagasan melalui model matematika yang dapat berupa kalimat dan persamaan matematika, diagram, grafik, atau tabel. Salah satu tujuan pembelajaran matematika adalah melatih cara berpikir dan bernalar dalam menarik kesimpulan. Materi matematika dan penalaran matematika merupakan dua hal yang tidak dapat dipisahkan, yaitu materi matematika dipahami melalui penalaran, dan penalaran dipahami dan dilatihkan melalui belajar materi matematika, sehingga kemampuan penalaran matematis sangat penting dan dibutuhkan dalam mempelajari matematika.

Kaput dan Maria dalam Jacob, dkk( 2007: 260) mengungkapkan bahwa "algebric reasoning is looked on as a process where to generalizing student collects thoughts mathematics of example hordes, proving the generalizing through argument discourse, expressing it formally according to age level", yang memiliki makna bahwa penalaran aljabar adalah suatu proses menggeneralisasi ide-ide matematika dari sekumpulan contoh, membuktikan generalisasi tersebut melalui wacana argumentasi, mengekspresikannya secara formal dan sesuai dengan tingkatan usia. Kemampuan penalaran aljabar dapat menunjukkan tinggi rendahnya penguasaan matematika siswa pada pokok bahasan yang melibatkan masalah penalaran aljabar. Salah satu tujuan dari penalaran aljabar adalah untuk mengembangkan cara-cara yang berbeda untuk mewakili situasi dunia nyata, mewakili ide-ide matematika dalam gambar, tabel, grafik dan kata-kata yang memungkinkan kita untuk menggunakan matematika sebagai cara berkomunikasi.

Pembelajaran matematika Sekolah Dasar (SD) dan Sekolah Menengah Pertama (SMP) harus memusatkan perhatian lebih besar pada persiapan siswa menghadapi tantangan lebih lanjut pada matematika SMP dan SMA termasuk aljabar. Siswa sering mengalami kesulitan ketika mereka mengalami kesulitan ketika mereka mengalami transisi belajar dari aritmetika di SD ke aljabar di SMP dan SMA. Kriegler (2011) menyatakan bahwa berpikir aljabar menjadi suatu pegangan untuk belajar dan mengajar matematika untuk mempersiapkan siswa berhasil dalam matematika. Pernyataan Kriegrel ini sejalan dengan ungkapan Mc Clure (2009) yang mengatakan bahwa salah satu pendekatan untuk membuat kuriulum matematika lebih terpadu adalah mengembangkan berpikir aljabar siswa di semua tingkatan kelas.

Kriegler (2011) berpendapat bahwa terdapat dua komponen utama dalam berpikir aljabar, yaitu berkenaan dengan : 1) pengembangan alat berpikir matematis, dan 2) kajian ide aljabar dasar. Alat berpikir matematis adalah kebiasaan berpikir secara analitis, keterampilan memecahkan masalah, keterampilan 
bernalar, dan keterampilan mereprentasi. Ide aljabar dasar merupakan domain dimana alat berpikir matematis dapat berkembang, yaitu materi pelajaran yang berkaitan dengan aljabar. Menurut Mc Clure (2009), berpikir alajabar adalah cara tertentu berpikir, termasuk menganalisis hubungan antara kuantitas, memperhatikan struktur, mempelajari perubahan, generalisasi, pemecahan masalah, pemodelan, justifikasi, membuktikan dan memprediksi. Berdasarkan pendapat kedua ahli tentang berpikir aljabar merupakan elemen penting dan mendasar dari berpikir dan penalaran matematis. Namun di sisi lain, masih sering ditemukan adanya masalah pada kemampuan berpikir aljabar siswa.

Siswa yang belajar matematika dari SD ke SMP mengalami transisi yang cukup sulit. Hal ini disebabkan kurikulum matematika di SD lebh menekankan pada aritmetika (perhitungan). Siswa harus melakukan banyak penyesuaian untuk belajar aljabar di SMP. Aritmetika berkaitan dengan angka dan operasi hitung, demikian juga dengan aljabar, namun aljabar lebih banyak menggunakan bahasa simbolik atau sering disebut dengan variabel, dan berfokus pada hubungan antara variabel tersebut. Misalnya dalam aritmetika di SD terdapat relasi antara operasi penjumlahan dan pengurangan. Bentuk penjumlahan $35+$ $42=77$ ekuivalen dengan $35=77-42$. Namun siswa yang baru belajar aljabar di tingkat SMP akan kesulitan ketika menemukan bentuk $\mathrm{x}+42=77$ yang ekuivalen dengan $x=77-42$. Kesalah juga sering terjadi dalam memaknai bentuk aljabar 2x. Di dalam aljabar 2x berarti $2 \mathrm{x} x$, namun banyak siswa yang memaknai bahwa $2 x=20+x$.

Dari pengalaman siswa seperti ini, banyak siswa yang tidak menyukai aljabar, seperti yang di ungkapkan oleh Geer (2008) sebagai berikut. Sebagian besar siswa, pengalaman memanipulasi simbol secara umum memberikan kesan yang negatif. Hal ini dapat berakibat kesulitan siswa mempelajari matematika pada tingkat sekolah yang lebih tinggi, karena aljabar merupakan pintu gerbang untuk mempelajari matematika dan matematika merupakan ilmu yang hierarki.

Kenyataan di lapangan menunjukkan bahwa pembelajaran matematika khususnya pokok bahasan aljabar belum sesuai dengan yang diharapkan. Kegiatan pembelajaran biasanya difokuskan untuk melatih siswa terampil menjawab soal matematika, sehingga pemahaman dan penalaran aljabar terabaikan. Selain itu, Berdasarkan observasi awal di MTsN BauBau melalui wawancara yang dilakukan oleh peneliti dengan beberapa orang guru matematika yang mengajar menyatakan bahwa kemampuan penalaran aljabar siswa itu rata-rata masih tergolong rendah. Sebagian besar siswa tidak dapat menyelesaikan masalah penalaran aljabar dalam bentuk persamaan dengan benar, tidak dapat menentukan starategi yang cocok digunakan untuk menyelesaikan masalah aljabar dan siswa tidak dapat mengidentifikasi hubungan perkalian yang ada pada masalah penalaran aljabar.

Dengan demikian perlu dikaji tentang strategi dalam menyelesaikan masalah aljabar, kaitan antara strategi dalam menyelesaikan masalah aljabar dengan penalaran aljabar. Selain itu, diperoleh juga indikasi penyebab rendahnya kemampuan penalaran aljabar siswa diantaranya adalah siswa merasa bosan dalam belajar, siswa pasif dalam pembelajaran, siswa tidak mandiri dalam mengkonstruksi pengetahuannya dan siswa tidak terlatih mengembangkan kemampuan penalaran aljabarnya. Hal tersebut menunjukkan bahwa bukanlah bidang studi matematika yang sulit dipelajari, tetapi disebabkan karena pembelajaran yang diterapkan tidak cocok dengan kebutuhan siswa dan pembelajaran yang berlangsung tidak bermakna bagi siswa. 
Kemampuan penalaran tidak hanya dibutuhkan siswa ketika mereka belajar matematika, tetapi dibutuhkan agar kelak mereka menjadi manusia yang dapat menganalisis setiap masalah yang muncul secara jernih, memecahkan masalah secara logis Shadiq (2007: 7). Salah satu jenis penalaran yakni penalaran aljabar telah banyak dipelajari oleh para peneliti dan mereka setuju bahwa penalaran aljabar merupakan konsep penting bagi siswa.

Beberapa hasil penelitian mengidentifikasi bahwa rata-rata kemampuan penalaran aljabar siswa masih tergolong rendah. Seperti yang dikemukakan oleh Murniati (2013: 6-7) bahwa kemampuan penalaran aljabar siswa tidak berkembang sebagaimana yang diharapkan khususnya pada materimateri aljabar. Hal ini, dilihat dari penyelesaian soal ulangan harian siswa untuk materi bentuk aljabar, relasi fungsi dan persamaan garis lurus masih rendah. Para siswa masih kesulitan dalam melakukan operasi tambah, kurang, kali dan bagi bentuk aljabar, terutama yang menggunakan bilangan bulat dan suku banyak. Para siswa masih kesulitan dalam menggunakan simbol-simbol. Selain itu, berdasarkan hasil wawancara beberapa siswa mengungkapkan bahwa materi yang dirasakan paling sulit dalam matematika adalah aljabar. Salah satunya penyebabnya terlalu banyak simbol dan mereka bingung menggunakannya. Berbagai hasil analisis refleksi, wawancara, serta koreksi terhadap hasil pelajaran siswa pada kelas 8 tahun pelajaran 2013/2014 tentang operasi bentuk aljabar menunjukkan siswa lemah dalam menyelesaikan operasi aljabar dan memfaktorkan. Hal ini juga merupakan indikasi bahwa pembelajaran selama ini belum bermakna karena proses melupakan lebih cepat terjadi sehingga belum menimbulkan pemahaman materi yang dipelajari.

Belajar matematika disebut bermakna apabila siswa mengalami sendiri apa yang dipelajari, daripada hanya mengetahui secara lisan saja. Kebermaknaan belajar matematika dipengaruhi oleh cara guru menyampaikan pembelajaran matematika itu sendiri. Sudrajat (2011: 1) berpendapat bahwa salah satu masalah yang dihadapi dunia pendidikan kita adalah masalah lemahnya proses pembelajaran. Dalam proses pembelajaran, siswa kurang didorong untuk mengembangkan kemampuan berpikir. Oleh karena itu, guru seharusnya menciptakan proses pembelajaran yang baik yaitu pembelajaran yang dapat mengembangkan kemampuan berpikir siswa dan melibatkan siswa secara aktif.

Problem Based Learning sebagai model pembelajaran yang dapat menggunakan masalah nyata sebagai konteks bagi siswa untuk belajar berpikir kritis, keterampilan memecahkan masalah, dan memperoleh pengetahuan mengenai esensi materi pembelajaran (Duch dalam Nurkholis, 2013). Keefektifan Problem Based Learning adalah siswa lebih aktif dalam berpikir dan memahami masalah penalaran aljabar secara berkelompok dengan melakukan penyelidikan terhadap permasalahan sehingga mereka mendapatkan kesan yang mendalam dan lebih bermakna tentang masalah yang mereka pelajari.

Model pembelajaran Problem Based Learning yang biasa dikenal dengan pembelajaran berbasis masalah disini adalah penyelesaian soal melalui tahapantahapan sehingga dapat membantu dan mengarahkan siswa menemukan solusi penyelesaiannya. Dengan diberikan masalah-masalah seperti itu, diharapkan dapat mendorong siswa mampu menyelesaikan permasalahan aljabar. Selain itu, dalam proses pembelajaran Problem Based Learning merupakan suatu model pembelajaran yang mengangkat satu masalah aktual sebagai satu pembelajaran yang menantang dan menarik, dimana siswa diharapkan dapat belajar menyelesaikan masalah tersebut secara adil dan obyektif. Pembelajaran 
melalui model Problem Based Learning berbeda dengan model pembelajaran konvensional dilihat dari segi proses pembelajaran, yakni dalam pembelajaran konvensional menggunakan metode ceramah dan tanya jawab, menekankan pada proses penyampaian materi secara verbal dari seorang guru kepada kelompok siswa dengan maksud agar siswa dapat menguasai materi pelajaran secara optimal.

Tujuan penelitian ini adalah untuk mendeskripsikan kemampuan penalaran aljabar siswa yang diajar dengan model pembelajaran Problem Based Learning, Untuk mendeskripsikan kemampuan

\section{METODE PENELITIAN}

Jenis penelitian yang digunakan Quasi Experimental dengan pretestposttest group design. Populasi dalam penelitian ini adalah siswa MTSN 1 Baubau. dimana kelas tersebut memiliki enam kelas paralel. Teknik pengambilan sampel menggunakan purposif sampling yaitu mengambil dua kelas paralel yang homogen berdasarkan hasil uji homogenitas. Untuk memilih kelas eksperiman digunakan random kelas.

\section{HASIL PENELITIAN}

Data dalam penelitian ini terdiri atas data kualitatif dan data kuantitatif. Data kualitatif diperoleh dari hasil observasi selama proses pembelajaran. Sedangkan data kuantitatif diperoleh dari hasil tes kemampuan penalaran aljabar dengan menggunakan model pembelajaran Problem Based Learning dan model konvensional, baik sebelum (pretes) maupun sesudah (postes) pembelajaran. Pada analisis deskriptif kualitatif dikemukakan peningkatan kemampuan siswa pada setiap variabel yang diteliti dan berbagai faktor yang mempengaruhinya, serta bagaimana tanggapan dan aktivitas siswa terhadap kelas yang menggunakan model pembelajaran Problem Based Learning dan model konvensional. penalaran aljabar siswa yang diajar dengan model pembelajaran konvensional, untuk menganalisis peningkatan kemampuan penalaran aljabar siswa yang diajar dengan model pembelajaran Problem Based Learning, untuk menganalisis peningkatan kemampuan penalaran aljabar siswa yang diajar dengan model pembelajaran konvensional, untuk menganalisis peningkatan kemampuan penalaran aljabar siswa yang diajar dengan model pembelajaran Problem Based Learning lebih tinggi dari pada siswa yang diajar dengan model pembelajaran konvensional.

Penelitian ini melibatkan tiga variabel yang terdiri dari dua variabel bebas (independent) dan variabel terikat (dependent). Variabel bebas dalam penelitian ini adalah model pembelajaran yang terdiri atas model problem based learning dan model pembelajaran konvensional, variabel terikat dalam penelitian ini adalah kemampuan penalaran aljabar siswa.

Sedangkan pada analisis inferensial dikemukakan hasil-hasil pengujian hipotesis baik untuk mengungkapkan perbedaan peningkatan kemampuan penalaran aljabar yang menggunakan model pembelajaran Problem Based Learning dan model konvensional.

Penelitian ini melibatkan dua kelompok siswa yang berbeda, sehingga analisis statistik yang digunakan adalah uji perbedaan rata-rata $\mathrm{N}$-Gain kemampuan penalaran aljabar yang menggunakan model pembelajaran Problem Based Learning dan model konvensional dilakukan dengan uji perbedaan rata-rata ttes sampel independent. Sebelum dilakukan analisis, terlebih dahulu dilakukan uji normalitas dan uji 
homogenitas variansi populasi. Untuk uji normalitas distribusi data menggunakan uji Kolmogorov-Smirnov $Z$, dan uji homogenitas varians populasi menggunakan uji Levene dengan bantuan program pengolah data SPSS - 20 for Windows.

Hasil analisis deskriptif terhadap data kemampuan penalaran aljabar siswa kedua kelompok pembelajaran disajikan pada Tabel berikut:

Tabel 1. Deskripsi Data Kemampuan Penalaran Aljabar Siswa

Statistik

Problem Based Learning

\begin{tabular}{ccccccc} 
& Pretes & Postes & N-Gain & Pretes & Postes & N-Gain \\
\hline N & 30 & 30 & 30 & 30 & 30 & 30 \\
Rata-rata & 35,1113 & 55,8333 &, 3083 & 33,8523 & 43,1113 &, 1453 \\
Standar Deviasi & 14,68683 & 10,32517 &, 13529 & 10,01739 & 13,51837 &, 13190 \\
Maksimum & 60,00 & 72,50 &, 59 & 51,11 & 68,89 &, 42 \\
Minimum & 8,89 & 30,00 &,- 13 & 17,78 & 17,78 &,- 08 \\
\hline
\end{tabular}

Berdasarkan rata-rata kemampuan penalaran aljabar siswa tersebut, terjadi perbedaan setelah pembelajaran. Hal ini ditunjukkan oleh perbedaan rata-rata antara kelas yang mendapat model pembelajaran Problem Based Learning dan kelas yang mendapat pembelajaran konvensional sebesar 12,722.

Gain ternormalisasi (N-Gain) kemampuan penalaran aljabar baik pada kelas eksperimen I maupun kelas eksperimen II. Rata-rata (mean) gain ternormalisasi yang diperoleh dari perhitungan ini, merupakan gambaran peningkatan kemampuan penalaran aljabar siswa yang pembelajarannya menggunakan model pembelajaran problem based learning maupun pembelajarannya menggunakan model pembelajaran konvensional. Selanjutnya dengan melihat perolehan rata-rata skor $\mathrm{N}$ Gain siswa dari kelompok model problem based learning sebesar 0,3083 lebih besar dibandingkan dengan perolehan rata-rata skor N-Gain siswa dari kelompok pembelajaran konvensional sebesar 0,1453 .

Tabel 2. Data N-Gain Kemampuan Penalaran Aljabar

\begin{tabular}{cccccr} 
Kelompok & N & \multicolumn{4}{c}{ Kemampuan Penalaran Aljabar } \\
& & $\bar{X}$ & $\begin{array}{c}\text { tandar } \\
\text { Deviasi }\end{array}$ & Min. & Maks. \\
\hline Eksperimen I & 30 & 0,3083 & 0,13529 & $-0,13$ & 0,59 \\
Eksperimen II & 30 & 0,1453 & 0,13190 & $-0,08$ & 0,42 \\
\hline
\end{tabular}

Untuk melihat kemampuan penalaran keadaan awal sebelum pembelajaran berlangsung, rata-rata kemampuan penalaran aljabar siswa yang akan mendapat model Problem Based
Learning sebesar 35.11, nilai maksimum 60.00, nilai minimum 8.89 , dan standar deviasi 14.69 dan kelas yang mendapat pembelajaran konvensional mempunyai rata-rata 33.85 , nilai maksimum 51.11, 
nilai minimum 17.78 , dan standar deviasi 14.69. Dari hasil analisis kemampuan penalaran aljabar siswa setiap kelas sampel dapat dilihat pada Gambar 1 berikut:

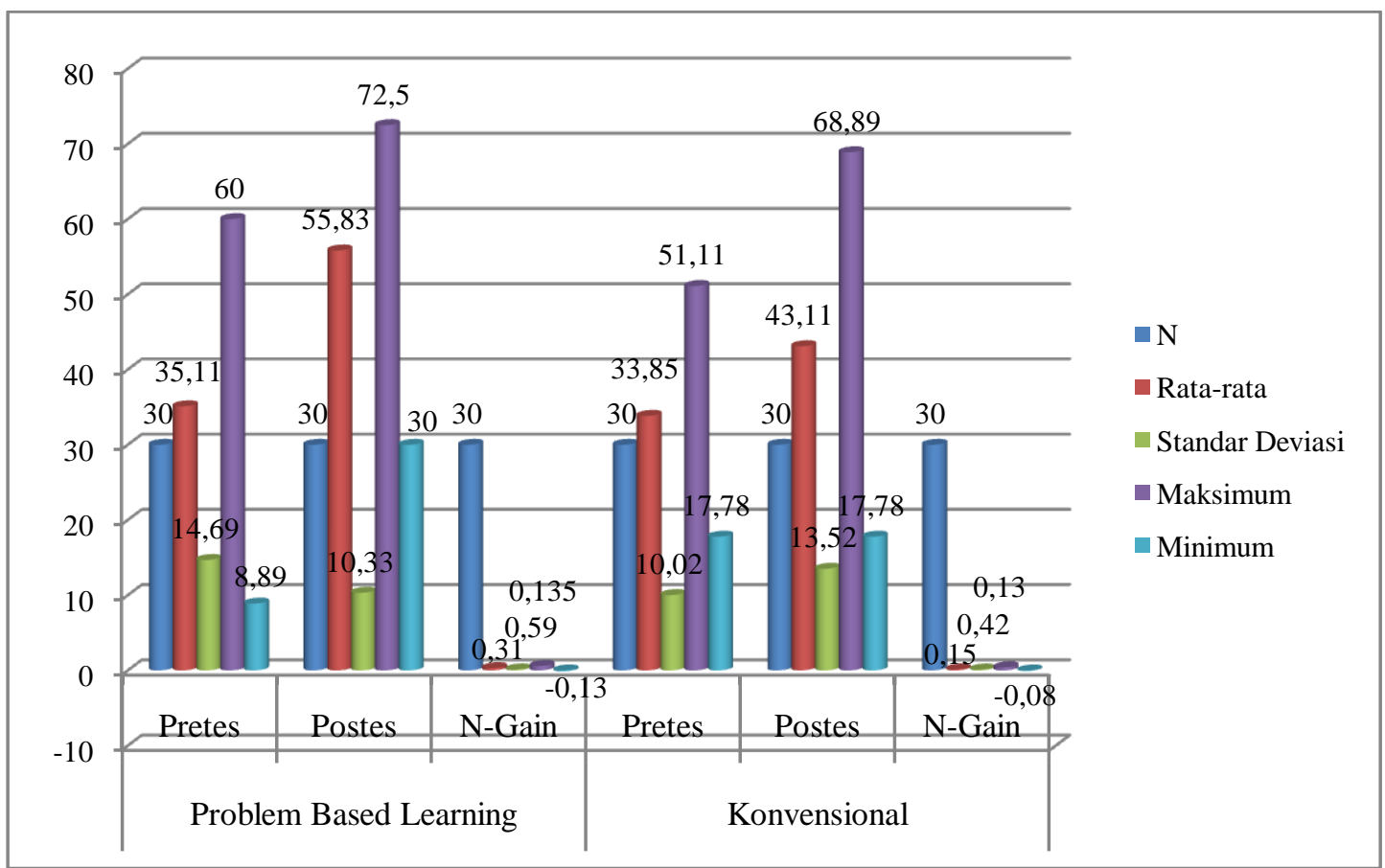

Gambar 1 Analisis Deskriptif Hasil Tes Kemampuan Penalaran aljabar Siswa

Pada Gambar 4.1 terlihat bahwa rata-rata kemampuan penalaran aljabar siswa yang telah mendapat pembelajaran problem based learning relatif berbeda dengan siswa yang mendapat pembelajaran konvensional. Hal tersebut, ditunjukkan bahwa rata-rata kemampuan penalaran aljabar siswa yang telah mendapat pembelajaran problem based learning sebesar 55,83 lebih besar dari rata-rata kemampuan penalaran aljabar siswa yang telah mendapat pembelajaran konvensional sebesar 43,11. Disajikan pada gambar 2 berikut:

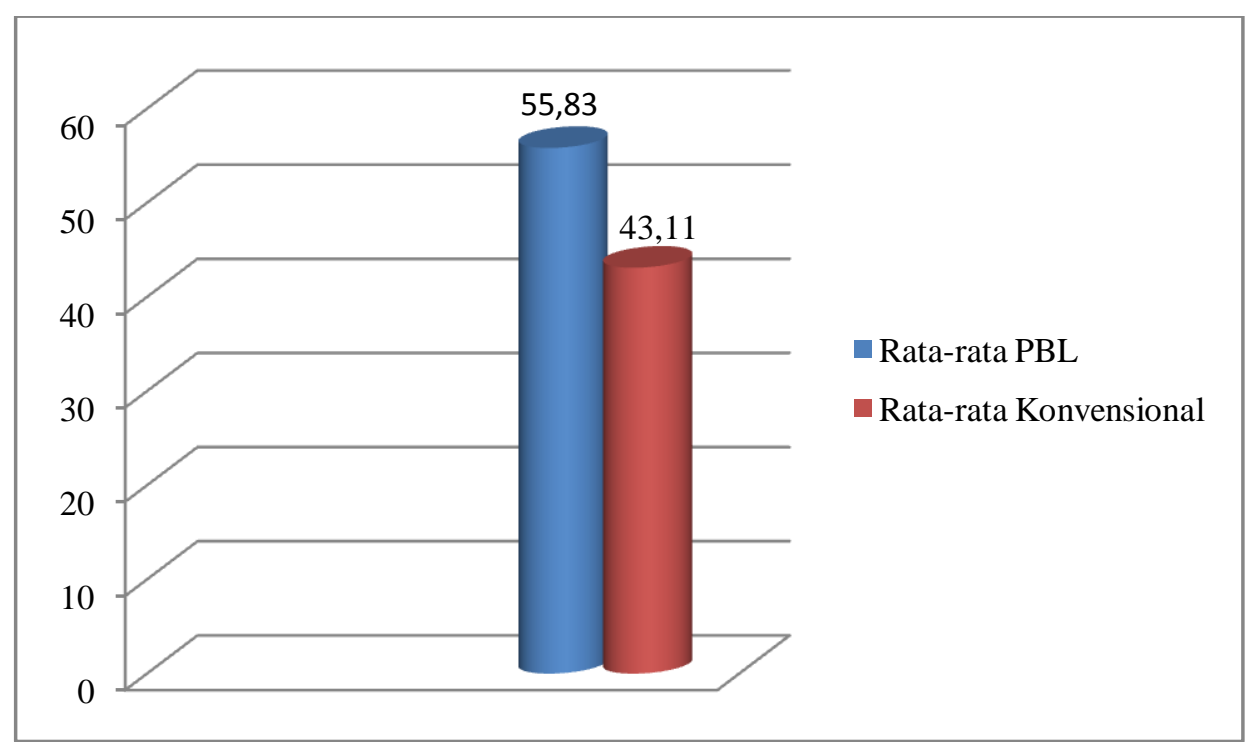

Gambar 2. Rata-rata Hasil Tes Kemampuan Penalaran aljabar Siswa

Peningkatan Kemampuan Penalaran Aljabar Siswa Melalui Problem Based Learning Dan Konvensional Pada Siswa Madrasah Tsanawiah (Elfiyanti Sermatan, Fahinu, Zamsir) 


\section{PEMBAHASAN}

Faktor model pembelajaran yang digunakan guru berpengaruh terhadap aktivitas siswa di kelas selama mengikuti proses pembelajaran. Pada pembelajaran konvensional, guru merupakan model, pusat kegiatan proses pembelajaran, sumber pengetahuan, dan kurang melibatkan siswa secara aktif dalam kegiatan belajar. Akibatnya, siswa menjadi malas, kurang tertarik memperhatikan materi yang dipelajari, bosan, tidak senang belajar matematika, dan tidak memahami matematika secara mendalam sehingga cepat lupa atau pembelajaran tidak bermakna. Siswa merasa bahwa belajar mengikuti petunjuk guru, tidak perlu kreatif, dan yang penting semua yang disampaikan guru dikuasai. Pembelajaran seperti ini kurang menantang, kurang menarik, dan kurang mengembangkan potensi berpikir siswa. Akibatnya, siswa tidak mampu menyelesaikan masalah-masalah yang lebih menantang dan sulit yang membutuhkan proses berpikir tingkat tinggi seperti penalaran aljabar siswa dan kemampuan berpikir matematis lainnya.

Penalaran aljabar siswa tidaklah mudah dilakukan. Oleh karena itu, dibutuhkan suatu model pembelajaran yang memudahkan siswa melakukan suatu penalaran aljabar. Model pembelajaran yang dimaksud adalah model pembelajaran Problem Based Learning karena dengan model pembelajaran tersebut dapat menumbuhkan minat siswa untuk belajar matematika sehingga dapat meningkatkan kemampuan penalaran aljabarnya.

Kemampuan penalaran aljabar siswa diperoleh melalui tes kemampuan penalaran aljabar siswa setelah dilakukan proses pembelajaran. Siswa memiliki kemampuan penalaran aljabar ditunjukkan dengan kemampuan generalisasi dari aritmetika dan pola yang ada di matematika, menggunakan simbol, pembelajaran tentang struktur dan sistem bilangan, pembelajaran tentang pola dan fungsional dan pemodelan matematika. Dalam proses pembelajaran matematika siswa tidak hanya bisa menggunakan rumus yang diberikan oleh guru, tetapi siswa juga mampu untuk menggunakan nalar dalam penyelesaian masalah matematika. Pembiasaan ini berkaitan dengan model pembelajaran yang digunakan guru yang dimiliki siswa, karena kedua faktor tersebut tidak lepas dari aktivitas siswa di sekolah.

Adanya perbedaan kemampuan penalaran aljabar siswa yang mendapat model pembelajaran Problem Based Learning dengan siswa yang mendapat pembelajaran konvensional disebabkan karena kondisi pada proses pembelajaran yang dilakukan berbeda. Dalam proses pembelajaran dengan menggunakan model problem based learning, siswa merupakan sentral dalam proses pembelajaran, memfasilitasi siswa untuk melakukan penyelidikan, sehingga siswa tertarik dalam mengikuti proses pembelajaran dan berperan aktif dalam mengkonstruksi kemampuan penalaran aljabarnya. Oleh karena itu, dengan menggunakan model problem based learning dapat mengembangkan kemampuan penalaran aljabar siswa.

Problem based learning dirancang untuk membantu siswa mengembangkan keterampilan berpikir dan keterampilan menyelesaikan masalah dalam hal ini adalah kemampuan penalaran aljabar. Problem based learning diawali dengan guru mengarahkan siswa pada masalah dalam pembelajaran persamaan linear satu variabel, memberikan masalah persamaan linear satu variabel dalam konteks nyata. Hal ini dapat membangkitkan rasa ingin tahu siswa sehingga mereka tertarik untuk menyelidiki masalah persamaan linear satu variabel. Setelah siswa menerima orientasi terhadap masalah, selanjutnya siswa membentuk kelompok belajar dan menyelidiki dan menyelesaikan 
permasalahan-permasalahan yang diberikan dalam LKS. Masalah yang diberikan di LKS disesuaikan dengan situasi masalah yang otentik dan bermakna yang dapat memberikan kemudahan kepada siswa untuk melakukan penyelidikan yang dilakukan secara kelompok dapat membantu menumbuhkembangkan penyelidikan yang dilakukan serta memudahkan siswa dalam pengumpulan data atau informasi yang diperlukan dalam proses penyelidikan. Setelah pengumpulan data tersebut, masing-masing kelompok siswa mendiskusikan solusi dari masalah yang ada.

Melalui aktivitas diskusi, guru memberikan bimbingan pada kelompok siswa yang mengalami kesulitan. Dengan ini, siswa diharapkan mampu memperoleh pemahaman yang lebih baik terhadap konsep matematika yang mereka pelajari dan siswa juga diharapkan menjadi pemecah masalah yang baik. Selanjutnya dalam pembelajaran problem based learning, hasil diskusi setiap kelompok dalam pemecahan masalah kemudian dipresentasikan dalam diskusi kelas. Proses ini mengungkap pendapat siswa tentang proses kerja kelompok yang telah dilakukan. Guru dapat memberikan umpan balik terkait proses dan hasil pemecahan masalah yang diperoleh untuk

\section{KESIMPULAN DAN SARAN}

Hasil analisis data menunjukkan bahwa sebelum pembelajaran, rata-rata kemampuan penalaran aljabar siswa, setelah mendapat pembelajaran Problem Based Learning sebesar 55,83 yang mendapat pembelajaran konvensional sebesar 48,11. Ditinjau dari rata-rata kemampuan penalaran aljabar siswa berdasarkan kategori sedang dan rendah antar kedua kelompok pembelajaran, maka rata-rata kemampuan penalaran aljabar siswa pada kategori sedang dan rendah untuk siswa yang mendapat pembelajaran Problem Based Learning lebih baik menanamkan konsep-konsep matematika yang dipelajari.

Kemampuan penalaran aljabar juga merupakan kemampuan siswa dalam memecahkan masalah aljabar matematika. Siswa yang memiliki kemampuan penalaran aljabar ditunjukkan oleh kemampuannya dalam mengeneralisasi dari aritmetika dan pola yang ada di matematika, menggunakan simbol, pembelajaran tentang struktur dan sistem bilangan, pembelajaran tentang pola dan sistem bilangan, dan pemodelan matematika. Peningkatan kemampuan ini sangat dipengaruhi oleh penggunaaan model pembelajaran.

Ditinjau dari perbedaan kemampuan penalaran aljabar pada setiap kategori berdasarkan model pembelajaran diperoleh bahwa siswa yang mendapat pembelajaran model pembelajaran Problem Based Learning mempunyai kemampuan penalaran aljabar lebih baik daripada siswa yang mendapat pembelajaran konvensional.

Berdasarkan uraian di atas dapat disimpulkan bahwa ada keterkaitan antara model problem based learning dengan kemampuan penalaran aljabar siswa. Penerapan model problem based learning secara signifikan dapat meningkatkan kemampuan penalaran aljabar siswa.

daripada siswa yang mendapat pembelajaran konvensional. Uraian tersebut menunjukkan adanya pengaruh yang lebih besar dari model pembelajaran Problem Based Learning dibandingkan dengan pembelajaran konvensional.

Adanya perbedaan kemampuan penalaran aljabar siswa yang mendapat model pembelajaran Problem Based Learning dengan siswa yang mendapat pembelajaran konvensional disebabkan karena kondisi pada proses pembelajaran yang dilakukan berbeda. Dalam proses pembelajaran dengan menggunakan model 
problem based learning, siswa merupakan sentral dalam proses pembelajaran, memfasilitasi siswa untuk melakukan penyelidikan, sehingga siswa tertarik dalam mengikuti proses pembelajaran dan berperan aktif dalam mengkonstruksi kemampuan penalaran aljabarnya. Oleh karena itu, dengan menggunakan model problem based learning dapat mengembangkan kemampuan penalaran aljabar siswa.

Berdasarkan hasil analisis, pembahasan dan kesimpulan dalam penelitian ini dapat dikemukakan saransaran sebagai berikut: Model pembelajaran problem based learning hendaknya digunakan sebagai salah satu alternatif

\section{DAFTAR PUSTAKA}

Arikunto, S. 2009. Dasar-Dasar Evaluasi Pendidikan. Jakarta: Bumi Aksara.

Artzt, Alice \& Yaloz-Femia, Shirel. 1999. Mathematical Reasoning during Small-Group Problem Solving. Dalam Developing Mathematical Reasoning in Grades K-12. (Edt) Stiff, Lee V. NCTM, Reston, Virginia.

Armiati Amin. 2012. Peningkatan Kemampuan Penalaran Matematis, Komunikasi Matematis dan Kecerdasan Emosional Mahasiswa melalui Pembelajaran Berbasis Masalah. Disertasi PPS UPI. Tidak diterbitkan.

Brickell, G., Brian F., Barri H. 2002. Developing Informal Reasoning Skill in III Structured Evironment : A Case Study in to Problem Solving Strategies. Australia : ASCILITE Australian Research Council Grand.

BSNP (Badan Standar Nasional Pendidikan). 2006. Standar Isi KTSP, Jakarta.

Curcio, dan Stiff. 1999. Developing Matheatical Reasoning in Grades $K$ - model pembelajaran bagi guru untuk mengoptimalkan kemampuan penalaran aljabar siswa, Untuk menggunakan model problem based learning, guru perlu memperhatikan waktu pembelajaran dan lebih mengontrol siswa yang bermasalah dalam kemampuan penalaran aljabar, khusunya yang terkategori rendah yakni dengan melatihkan soal-soal yang melibatkan penalaran aljabar dalam pembelajaran, Peneliti selanjutnya, hendaknya dapat menggali lebih jauh tentang kemampuan penalaran aljabar dengan menggunakan masalah-masalah penalaran aljabar yang lebih variatif dan menarik.

12; National Council of Teachers of Mathematics. Reston. Virginia.

Dahlan, J.A. 2004. Meningkatkan Kemampuan Pemahaman dan Penalaran Matematika Siswa Sekolah Lanjutan Tingkat Pertama melalui Pendekatan Open-Ended. Disertasi PPS UPI Bandung : Tidak diterbitkan.

Depdikbud. 1984. Filsafat Ilmu, Materi Dasar Pendidikan Program Akta Mengajar V (Buku 1A), Jakarta : Universitas Terbuka.

Depdiknas. 2001. UU No. 20 Tahun 2003 Tentang Sistem Pendidikan Nasional, Jakarta : Depdiknas. 